\title{
GENETIC DIVERSITY OF STONE FRUIT VARIETIES (GENUS Prunus L.) RESISTANT TO LEAF SPOT
}

(review)

\section{M.S. LENIVTSEVA ${ }^{1}$, E.E. RADCHENKO'1, A.P. KUZNETSOVA ${ }^{2}$}

\author{
${ }^{1}$ Federal Research Center the N.I. Vavilov All-Russian Institute of Plant Genetic Resources, Federal Agency of Scien- \\ tific Organizations, 42-44, ul. Bol'shaya Morskaya, St. Petersburg, 190000 Russia, e-mail len-masha@yandex.ru \\ (corresponding author), Eugene_Radchenko@rambler.ru; \\ ${ }^{2}$ North Caucasian Regional Research Institute of Horticulture and Viticulture, Federal Agency of Scientific Organiza- \\ tions, 39, ul. 40-let Pobedy, Krasnodar, 350901 Russia \\ ORCID: \\ Lenivtseva M.S. orcid.org/0000-0002-2717-3038 \\ Radchenko E.E. orcid.org/0000-0002-3019-0306 \\ Kuznetsova A.P. orcid.org/0000-0003-4829-6640 \\ The authors declare no conflict of interests \\ Acknowledgements: \\ Supported by Russian Foundation for Basic Research (grant № 16-44-230323 p_a) and by the grant from Admin- \\ istration of Krasnodar Krai under the State Program of Federal Agency of Scientific Organizations \\ Received February 15, 2016
}

\section{Abstract}

The range of disease-resistant varieties and hybrids of stone fruits (genus Prunus L.) is quite wide. In Russia, these are the hybrids of sour cherry VP-1, Rubin, Vozrozhdenie № 1, Olymp, (A.F Kolesnikova et al., 1998), Pushkinskaya, Akvarel, Feya, Practichnaya, Zelenoglazka (R.A. Chmir, 2003), sour cherry varieties Livenskaya, Mtsenskaya, Novella, sweet cherry Poeziya, clonal rootstocks V-2180, V-2-230 (A.A. Gulyaeva et al., 2007), Rusinka, Businka, Yubileynaya 3, Pamyat Sakharova (O.N. Kartashova, 2009), AI, 3-115, 10-15 (A. Kuznetsova et al., 2010), sour cherry samples Hindenburg, Obnovlennaya, Nochka 2, Rannyaya 2, and sweet cherry varieties Muscatnaya Krasnaya, Royyal 23/16, Lamori Gin, Sladkaya Sentyabrskaya, Tseshenskaya Oktyabrskaya (M.S. Lenivtseva et al., 2010). The varieties Anshlag, Lasunya, Lyubimitsa Turovtseva (M.I. Turovtsev et al., 2011) are resistant in Ukraine, sour cherry cultivar Zhivitsa (E.P. Syubarova et al., 2002) is resistant in Belarus. In Lithuania, the resistance of varieties Big Starking, Griot Ukrainskij, Maraska, Samsonovka (D. Gelvonauskiene et al., 2004) is reported. In Poland, Melitopolska, Fortuna, Minister Podbielski, Zagoriewskaja varieties are resistant (G. Hodun et al., 2000; Z.S. Grzyb et al., 2004.). Cherry varieties Kareshova, Kashtanka, Vinka are considered resistant in the Republic of Moldova (E. Cheban, 2005). Also, the resistant samples are clones 5.55, 13.122 (B. Wolfram, 2000), varieties Almaz, Köröser Gierstädt, Coralin and species P. maackii, P. canescens (M. Schuster, 2004, 2008; M. Schuster et al., 2004, 2013, 2014) in Germany, cherry varieties Celeste and Giorgia (G. Romanazzi, 2005) in Italy, and Linda, 11/106, Piramis, Csengödi (Z. Rozsnyay et al., 2005; J. Apostol, 2008) in Hungary. In the USA, Almaz, Gisela 6, and P. canescens (P.S. Wharton et al., 2003; P.S. Wharton et al., 2005) are reported as resistant. In the review, we discuss a replenishment of effective resistance gene pools using world genetic resources and based on plant resistance studies. It was shown that Prunus leaf spot resistance usually dominates and is under monogenic, oligogenic or polygenic control. In hybrids, the manifestation of resistance character depends on whether a resistant parent was male or female one (A.M. Mikheev et al., 1978; O.S. Zhukov et al.,, 1981; A.F Kolesnikova, 1982; N.I Turovtsev et al., 1983; M.V. Kanshina, 2007; J. Apostol, 2000, 2008). Expression of resistance genes derived from the most popular donor, P. maackii Rupr., remains quite high in the second and third hybrid generations (I.E. Fedotova et al., 2001). Dominant resistance character is revealed in P. serrulata and P. maximowiczii (M.S. Chebotareva, 1993). The hybrids 85017, 82990, 83187, 85023 derived from crosses with Kuril, Sakhalin cherry species, $P$. maximowiczii and $P$. serrulata plants are recommended as donors of resistance to cherry leaf spot (N.G. Gorbacheva, 2011). A significant decrease in resistance is noticed in the interspecific hybrid Almaz (with P. maackii in the pedigree) which is widely used in breeding for immunity. Genetic diversity of cultivated varieties should be expanded by involving in breeding not only derivatives of $P$. maackii, but also other stone fruit species resistant to leaf spot such as $P$. kurilensis Miyabe, $P$. sargentii Rehd. (M. Schuster, 2004), P. incisa Thunb, P. pseudocerasus, P. subhirtella Mig. (M. Schuster, 2004; M. Schuster et al., 2004), P. concinna Koehne, P. conradinae (Koehne) Yu. et Li (M.S. Chebotareva, 1986), P. canescens Bois. (M.S. Chebotareva, 1986; M. Schuster et al., 2013, 2014; T. Stegmeir et al., 2014), P. padus L., P serotina Ehrh, P. asiatica 
Kom., P. incana Stev. (M.S. Chebotareva, 1986), P. glandulosa Thunb. (M.I. Vyshinskaya, 1984; M.S. Chebotareva, 1986). In breeding, the variability of pathogen populations must be considered

Keywords: stone fruits, leaf spot, resistance, wild Prunus L. species

One of the main reasons for the reduction of sweet cherry and cherry acreage is a severe infestation of varieties and rootstocks with cherry leaf spot. The causative agent of this disease is the fungus Coccomyces hiemalis (Higg.), the conidial stage Cylindrosporium hiemale (Higg.), syn. Blumeriella jaapii (Rehm) v. Arx. The most radical method to confront progressing cherry leaf spot diseases is search and creation of the pathogen resistant assortment of sweet cherry and cherry. A rational strategy of breeding for resistance to diseases and pests should involve the extension of the genetic diversity of cultivated varieties. The literature discusses several ways of solving the problem, including the alternation in time of cultivars with different resistance genes, selection of multiline varieties (mixtures of phenotypically similar lines differing in resistance genes), cultivation of varieties with different resistance genes in the area of the pathogen (mosaic), combining different resistance genes in one cultivar (gene stacking). Implementing any of these strategies is based on the study of inheritance of resistance and creation of new donors protected by effective resistance genes.

An intensive study of the resistance of genetic resources of stone fruits to C. hiemalis in Russia and the former Soviet Union was started in the late 1960s. Infestation of sweet and sour cherries with cherry leaf spot was analyzed in all the areas of distribution of the causative agent, i.e. in Central Russia [1], North Caucasus [2], Ukraine [3], the Republic of Moldova [4], Belarus [5], the Baltics [6] and Georgia [7]. The resistance of stone fruits was also studied in Germany $[8,9]$, Poland [10, 11], Romania [12] and the USA [13]. It was found that there are no highly resistant cherry and sweet cherry varieties, and a few varieties characterized by field resistance were selected. These are cherry varieties Pamyati Vavilova, Zhukovskaya, Komsomolskaya, Severyanka and Turgenevka for Central Russia [1], cherry varieties Seyanets 1, Seyanets 2, Zhukovskaya, Glubokskaya, Zvezdochka, Komsomolskaya, Pamyati Vavilova and sweet cherry varieties Aelita, Belobokaya rannyaya, Krasavitsa, Orlovskaya rozovaya and Severnaya for Belarus [5], sweet cherry cultivars Bigarro Oratovskogo, Vinka, Dneprovka, Izyumnaya, Konservnaya, Transportabelnaya and Frantsis for the Melitopol Region of Ukraine [3]. In large-scale screening, the following varieties were considered valuable: sweet cherry Yellow Glass, Schmidt and Emperor Francis from the United States, cherry Karneol, Morina, Safir and Topas from Germany, and cherry Jareniywka, Wloszkowice and Wryble from Poland [8-13].

A study of the total species diversity of stone fruit cultures have amply demonstrated that introgression is the most promising way of expanding the genetic diversity of sweet cherry and cherry for resistance to cherry leaf spot. These wild species are of interest for selection: cherries Prunus maackii Rupr. [syn. Cerasus maackii (Rupr.) Erem. et Simag., Padus maackii Komar., Laurocerasus maackii Schnaid.] [5, 14-20], P. kurilensis Miyabe [syn. C. nipponica var. kurilensis (Miyabe) Erem. et Yushev, C. kurilensis Kaban. et Vorobiev, P. nipponica var. kurilensis Wils.], P. sargentii Rehd. [syn. C. sargentii (Rehd.) Erem. et Yushev, Cerasus sachalinensis Komar. et Klob. Aliss.], P. maximowiczii Rupr. [syn. Padellus maximowiczii (Rupr.) Erem. et Yushev, C. maximowiczii Kom.] [5, 14, 17-20], P. serrulata Lindl. [syn. C. serrulata var. lannesiana (Carr.) Erem. et Yushev, C. serrulata G. Don.], P. incisa Thunb. [syn. C. incisa Lois.], P. pseudocerasus Lindl. [syn. C. pseudocerasus G. Don.], P. canescens Bois. [syn. C. canescens (Bois.) Erem. et Yushev], P. subhirtella Mig. [14, 17-22], P. concinna Koehne, P. conradinae (Koehne) Yu. et Li [17]; bird cherry P. padus L. [syn. 
Padus racemosa Gilib.], P. serotina Ehrh. [syn. Padus serotina Borkh.], P. asiatica Kom. [5, 17]; micro-cherry P. incana Stev. [syn. Cerasus incana Spash., Microcerasus incana Roem., Microcerasus incana var. araxina (Pojark.) Erem. et Yushev] [17], P. glandulosa Thunb., [syn. Cerasus glandulosa Lois., Microcerasus glandulosa (Thunb.) Roem.] [5, 17].

As a result of selection and breeding, a substantial fund of diseaseresistant varieties, hybrids, clonal rootstocks of sweet cherry and cherry has been created in Russia. There are interspecific hybrids and cherry varieties among them: VP-1, Rubin, Vozrozhdenie 1, Olimp, 30014, 31414 [23-24], Pushkinskaya, Akvarel, Dzhussi frut, Brilliant, Feya, Praktichnaya, Pamyati Vavilova, Kharitonovskaya, Ustoichivaya, Zelenoglazka [16]; the sour cherry varieties Livenskaya, Mtsenskaya, Novella and Orlitsa; sweet cherry Poeziya; the clonal rootstocks V-2-180, V-2-230, V-5-88, V-5-182 [25], Rusinka, Businka, Yubileynaya 3, Shakirovskaya, Ballada, Polyanka, Pamyat Sakharova [26], 3-90, 11-17, AI, 3115, 10-15 [27]; the sour cherry samples Hindenburg, Ujfehertha Fürthosh, Podbelskaya, Obnovlennaya, Lunered Mont Burhholder, Nochka 2 and Rannyaya 2; the sweet cherries Muskatnaya krasnaya, Orlovskaya (3734), Planeta, Polyanka 1043, Royal 23/16, Lamory Guigne, Sladkaya sentyabrskaya and Tseshenskaya oktyabrskaya [28].

In recent years, resistant varieties Anshlag, Lasunya, Lyubimitsa Turovtseva derived using sweet cherry Tseshenskaya Oktyabrskaya have been included in the Ukrainian State Register of Plant Varieties [29]. Sour cherry cultivars resistant to cherry leaf spot have been selected in Belarus (cultivar Zhivitsa) [30] and in Lithuania (cultivars Big Starking, Griot Ukrainskij, Maraska, Samsonovka, Oblacinska, Vytėnų žvaigždè and Recta) [31]. Cherry variety Karešova is moderately resistant to cherry leaf spot in Czechoslovakia [32]. In Poland, the resistant cherry varieties are Melitopolska, Fortuna, Minister Podbielski, Zagoriewskaja, Stevensbaer, Pomiati Vavilova and Oblacińska [11, 33]. The sweet cherry varieties Kareshova, Kashtanka, Vinka, Maslovskaya and Pozdnyaya Lermontova have been created in the Republic of Moldova [34]. In Bulgaria, the sweet cherry cultivar Patriotca Krima is resistant [35]. In Germany, the cherry clones 5.55, 13.122 and 19.130 [9] have been selected, as well as the varieties Almaz (Russian breeding), Köröser Gierstädt, Korai Pipacsmeggy, Coralin and P. maackii [18, 20, 36, 37]. In Italy, the sweet cherry varieties Celeste and Giorgia [38] have been created; in Hungary these are Linda, 11/106 and Piramis [39-41]. In the USA, Almaz and Gisela $6[21,22]$ are considered resistant. The cherry samples Almaz, Novella, Zhukovskaya, Pamyati Vavilova, Luch, Stepnoi Rodnik, Feya, Kharitonovskaya, VP-1, Rubin, Oblacinska and others are disease-resistant in different regions of Russia and abroad. The sweet cherry cultivars Sladkaya sentyabrskaya and Tseshenskaya oktyabrskaya are disease-resistant in the Krasnodar Krai, the Crimea and Ukraine [42].

This review is the first summarizing studies of genetic control of stone fruits resistance to cherry leaf spot in Russia and abroad.

It was shown that in combinations of cherry varieties resistant $\times$ resistant most of the seedlings had increased immunity to cherry leaf spot, and in families, obtained by crossing the susceptible samples, the plants with strong development of the disease dominated. The number of susceptable seedlings varied from $23.4 \%$ (Lyubskaya $\times$ Shirpotreb) to $65.7 \%$ (ground cherry $\times$ Shirpotreb). In direct and inverse crosses of resistant varieties with the susceptible ones, in most families more than half of the hybrid progeny was characterized by increased resistance to the pathogen of cherry leaf spot. The number of resistant plants varied from $52.9 \%$ (Tserapadus No. $1 \times$ Lyubskaya) to $95.4 \%$ (family Griot Moskovskij $\times$ Tserapadus No. 2) [43]. Similar results were obtained by A.A. Melesh- 
kevich in Belarus [44]. When resistant varieties were parents (Kistevaya $\times$ Novodvorskaya $2 / 3$ ), the hybrids showed relative resistance, in combinations of susceptible $\times$ susceptible parents, the susceptible seedlings prevailed.

Relatively resistant varieties Solnechnyi shar, Vinka and Melitopolskaya rozovaya have been obtained (Ukrainian Research Institute of Irrigated Horticulture, Melitopol), using the cherry variety Frantsis as s female parent. It is assumed that the influence of the maternal genotype on the manifestation of the resistance character in seedlings was more pronounced than of the paternal one. Crossing susceptable cultivars resulted in a high percentage of susceptible seedlings [3].

Sweet cherry seedlings in the hybrid families $8-14 \times 3-36,3-36 \times 6-72$, 3-36 $\times$ Yantarnaya had the highest resistance in Bryansk Province. The proportion of highly resistant seedlings in these families ranged from 23 to $50 \%$. In the analysis of 15 hybrid families of sour cherry, a high overall genetic diversity was revealed. It is due to the additive effects of genes in eight hybrid families, and to the nonadditive effects in seven ones. According to the author, resistance to cherry leaf spot is under control of oligogenes and polygenes [45].

In the works on the genetic control of cherry resistance to leaf spot and breeding, the experiments with the Maack cherry ( $P$. maackii) are mainly described. This species was involved in breeding by I.V. Michurin. When crossing the ground cherry with the Maack bird cherry (cherry), Michurin obtained Tserapadus 1. Later, a number of cerapaduses and padoceruses were created. From a hybrid population (Padocerus $\mathrm{M} \times$ cherry-sweet cherry Novosyolka) $\times \mathrm{Pa}-$ myati Vavilova, the hybrid A-135 (Almaz) was selected (I.V. Michurin AllRussian Research Institute of Genetics and Breeding of Fruit Plants ARRIGBFP, Michurinsk). O.S. Zhukov and L.A. Shchekotova [46] selected about $50 \%$ of highly resistant seedlings in the progeny from a cross of this hybrid with highly susceptible varieties. This hybrid was recommended as a source of monogenic resistance to cherry leaf spot. Analyzing crossing with the variety Lyubskaya revealed splitting $1: 1$, i.e. the resistance gene to cherry leaf spot was in a dominant state. The resistance gene of the hybrid Almaz is marked by the authors with the symbol $A$ [46]. In the further study of the progenies of this hybrid compared to relatively resistant variety Zhukovskaya and the highly susceptible variety Lyubskaya, the highest percentage of resistant seedlings was observed in the hybrid progeny, middle percentage was in variety Zhukovskaya and the lowest one was in cultivar Lyubskaya. Cherry varieties, differing in resistance, proved to be heterozygous by this character, therefore, the degree of cherry leaf spot infestation is controlled polygenically [46]. Adaptive donors, rootstocks and varieties resistant to cherry leaf spot were created on the basis of the hybrid Almaz. Subsequently, the cherry-bird cherry hybrids Brilliant, Korall, Luch, Stepnoi Rodnik, Feya and Kharitonovskaya were obtained, which, along with resistance to this dangerous disease, have a good quality of the fruit [47]. According to R.A. Chmir [16], the samples Padocerus B, Pushkin, Pushkinskaya, Akvarel, Dzhussi frut, Brilliant, Feya, Praktichnaya, Pamyati Vavilova, Kharitonovskaya, Ustoichivaya, Zelenoglazka are characterized by polygenic resistance to cherry leaf spot.

Crossing Maack cherry plants with sour cherry varieties (All-Russian Research Institute of Breeding Fruit Crops - ARRIBFC, Orel Province) resulted in hybrids $F_{1}$ and donors of resistance to cherry leaf spot VP-1, Rubin and 28889 [48]. Given the nature of the progeny splitting, the resistance of sample Tserapadus 28768 (VP-1) derived from self-pollination and free pollination is heterozygous. In the offspring of this sample there was a dominance of the characteristic, as the ratio of resistant and fragile seedlings was 3:1 [49]. 
As donors of resistance to cherry leaf spot and adaptability, the hybrids of cherry Vozrozhdenie 1 (Zolushka $\times$ VP-1), ELS PI 15-21 15-21 (VP-1 $\times$ Muza $F_{2}$ ) and ELS PI 14-1 (Muza $\times$ Vozrozhdenie $1 \mathrm{~F}_{3}$ ), tetraploid 1-36 (Shokoladnitsa $\times P$. serrulata Hally Tolivetta), triploids 1-13 (Shokoladnitsa $\times P$. incisa) and 2-13 (Shokoladnitsa $\times$ P. kurilensis Dolinsk 5) [50] may be suggested. Based on backcrossing cherry cultivars Pamyati Vavilova, Lyubskaya, Vladimirskaya, Zolushka, Muza, Turgenevka with derivatives of the Maack cherry, the ARIBFC hybrid fund was created, and promising seedlings were separated and multiplied. Differences in resistance to cherry leaf spot between the reciprocal hybrids $\mathrm{F}_{2}$ and $\mathrm{F}_{3}$ were not detected. Ageing and declined physiological condition of trees, as well as mass accumulation of the fungus led to a decreased resistance of the hybrids. However, Maack cherry retained high resistance in backcrosses not only in the second but also in the third generations [24].

According to E.N. Jigadlo and A.A. Gulyayeva [51], VP-1, 28889, Rubin, 30013, Olimp, 30020, Vozrozhdenie 1, Vozrozhdenie 2 (31414) and Dolgozhdannaya (ARIBFC) created on the basis of the Maack cherry are of interest for use in breeding as donors of mono-genic resistance to cherry leaf spot. The assessment of resistance of the sour cherry seedlings obtained from backcrossing with Maack cherry revealed a very small number of highly resistant plants. Thus, highly resistant progeny amounted $7.4 \%$ in VP-1 families from self-pollination, $11.1 \%$ in VP- $1 \times$ Vladimirskaya combination, $0.3 \%$ in VP- $1 \times$ sweet cherry Muskatnaya, $0.7 \%$ in Lyubskaya $\times 28889$ cross, $2.1 \%$ in Lyubskaya $\times$ Rubin cross, $2.6 \%$ in Lyubskaya urozhainyi klon $\times$ Rubin cross, and $7.7 \%$ in $31414 \times$ 33585 combination. A large part of resistant seedlings were observed in families obtained with a participation of VP-1. According to the authors, the use of distant hybrids of sour cherry with the Maack cherry in backcrossing with sour cherry leads to a decrease in resistance to cherry leaf spot in hybrid offspring. Hybrids resistant to cherry leaf spot were produced at Sverdlovsk breeding station of horticulture, i.e. 1-53-86, 1-35-89 and 1-39-89 with VP-1 involved, and 7-15-83, 837-82 with Almaz involved [52].

In crossing immune sample $P$. serrulata var. lannesiana (No. 2) with the susceptible sweet cherry varieties Krepysh, Kuban, Lyubimitsa Duki and after free pollination, resistance dominated in $F_{1}$ in the field experiments and under artificial inoculation. Obviously, the sample $P$. serrulata var. lannesiana No. 2 has a dominant resistance gene (genes). In combination P. serrulata var lannesiana No. $1 \times P$. avium L., there was complete dominance of resistance, however, in reciprocal crossing incomplete dominance was marked, which can be explained by the influence of the maternal cytoplasm. In families from crosses of Frantsuzskaya chernaya $\times P$. sargentii (Sakhalin cherry $3 / 75$ ) and Frantsuzskaya chernaya $\times P$. serrulata (Batumi 1), all seedlings were highly susceptible to the fungus. Afterwards, crossing $P$. serrulata var. lannesiana No. 2 with the susceptible sweet cherry variety Frantsuzskaya chernaya showed complete dominance of resistance. When using this sample as a male parent in crossing with the susceptible cherry variety Zhagarskaya, incomplete dominance of the trait was marked. The dominance of resistance, except for P. serrulata var. lannesiana No. 2, was also found in a sample of P. maximowiczii (the Maksimovich cherry) $[17,53]$.

Involving diploid species of the Kurile, Sakhalin, Maksimovich cherry and $P$. serrulata, hybrids $85017,82990,83187$, and 85023 were obtained, which are recommended as donors of resistance to cherry leaf spot [54]. The study of cherry leaf spot resistance of seedlings obtained by I.E. Fedotova and A.F. Kolesnikova in crossing $P$. incisa, $P$. serrulata, $P$. kurilensis, $P$. sargentii at hard infection loads showed that resistant seedlings from all the combinations used aver- 
aged $65.45 \%$, of which $32.93 \%$ were immune. The amount of immune seedlings depends on the interaction of polygenes of the maternal plant (variety) with oligogenes of the male parent (wild species). The seedlings obtained by crossing Rovesnitsa possessing high polygenic resistance with $P$. serrulata were infested by the fungus least of all [55].

In the United States, the Almaz variety obtained with the use of $P$. fruticosa 18-6-44 from Krymsk (Krasnodar region), as well as the sample GI 148-1 with a resistant species $P$. canescens in the pedigree, showed high resistance to cherry leaf spot after free pollination $[21,22,56]$. Note, Almaz variety was obtained using the Maack cherry, and GI 148-1 was created uisng P. canescens, that is, the resistance of these forms is probably under control of different genes. When infected by five monosporous fungal isolates collected from plants of different species and genera (cherry, sweet cherry, $P$. serotina, mahaleb cherry and plum), Almaz and GI 148-1 plants showed a slight injury caused by fungi from cherry, sweet cherry and mahaleb cherry. In Hungary, in studying inheritance of resistance to cherry leaf spot in variety Csengödi, Cultivars Érdi bötermö, Meteor korai, Érdi nagygyümölcsü, M 221, III-43/60, IV-2/152 were used as female parents; Csengödi, Érdi bötermö, Meteor korai and IV-2/152 served as male parents. A total of 35 resistant seedlings were identified of which 13 ones were tolerant. Cherry resistance to cherry leaf spot is determined by the recessive polygenes [5760]. In Serbia, genotypes Feketicka demonstrated different field resistance to cherry leaf spot [61]. In Germany, the inheritance of resistance to cherry leaf spot of species $P$. canescens, $P$. maackii is being studied [62].

Thus, resistance to cherry leaf spot pathogen in genus Prunus L. usually dominates and is under monogenic, oligogenic or polygenic control. Manifestation of the trait depends on the use of resistant plants as female or male parents. The dominance of resistance in $P$. serrulata and $P$. maximowiczii (the Maksimovich cherry) is revealed. Expression of cherry leaf spot resistance of the most popular donor, the Maack cherry, was observed in its hybrids in the second and third generations. The range of stone fruit varieties and hybrids resistant to the disease is quite wide. The Russian State Register of Selection Achievements admitted to use includes resistant varieties Novella, Rusinka, Businka, Kapelka, Feya, Kharitonovskaya created on the basis of the Maack cherry, the clonal rootstocks V-2-180, V-2-230, V-5-88, V-5-172, and sweet cherry varieties Anshlag, Lasunya, Lyubimitsa Turovtseva with sweet cherry resistant variety Tseshenskaya Oktyabrskaya in the pedigree. The sample GI 148-1 with a resistant species $P$. canescens in the pedigree showed high resistance to cherry leaf spot after free pollination. Note, most breeders use only derivatives of Almaz variety (with Maack cherry in pedigrees) as donors. However, as shown by our studies, clones of the fungus which can greatly infest this variety are sufficiently high frequent in the pathogen populations. It is necessary to improve genetic diversity of cultivated varieties by involving in breeding not only the Maack cherry derivatives, but other stone fruit plants resistant to cherry leaf spot such as $P$. $k u$ rilensis Miyabe, $P$. sargentii Rehd., P. incisa Thunb., P. pseudocerasus, P. subhirtella Mig., P. canescens Bois., P. concinna Koehne, P. conradinae (Koehne) Yu. et Li, P. padus L., P. serotina Ehrh., P. asiatica Kom., P. incana Stev., P. glandulosa Thunb. In breeding, one should take into account the variability of this pathogen populations.

\section{REFEREN C ES}

1. Kolesnikova A.F., D mit rova T.A. Selektsiya, sortoizuchenie, agrotekhnika plodovykh $i$ yagodnykh kul'tur, 1980, 10(2): 19-29 (in Russ.). 
2. B a rs u k ov a O.N., S h e s t a k o v I.I. Nauchnye trudy Maikopskoi opytnoi stantsii VIR, 1974, 8: 91-101 (in Russ.).

3. Turovtsev N.I., My a lova L.A., Levchenko V.A. Sadovodstvo, vinogradarstvo $i$ vinodelie Moldavii, 1983, 1: 43-44 (in Russ.).

4. B o ndare n k o A.I. V sbornike: Zashchita urozhaya [In: Crop protection]. Kishinev, 1976: 20-30 (in Russ.).

5. Vys hi n s a y a M.I. Iskhodnyi material dlya selektsii vishni $i$ chereshni na ustoichivost' $k$ kokkomikozu. Avtoreferat kandidatskoi dissertatsii [Initial material for use in breeding cherry plants resistant to coccomycosis. PhD Thesis]. Samokhvalovichi, 1984 (in Russ.).

6. Minky avi chy u A.I. V sbornike: Sostoyanie $i$ perspektivy razvitiya plodovodstva $v$ pribaltiiskikh respublikakh $i$ Leningradskoi oblasti [In: Condition and outlook of pomiculture in the Baltic republics and Leningrad region]. Vil'nyus, 1966: 138-145 (in Russ.).

7. B e d o id ze Z.Sh. Rezul'taty izucheniya kokkomikoza kostochkovykh Vostochnoi Gruzii. Avtoreferat kandidatskoi dissertatsii [A study of coccomycosis in stone fruit crops in the East Georgia. PhD Thesis]. Tbilisi, 1976 (in Russ.).

8. Burth U., Rams o n A. Hauptfruchtform der Sprühfleckenkrankheit der Kirsche auch in der DDR. Dt. Pflanzenschutzdienst, 1970, 24: 132.

9. Wo $1 \mathrm{fr}$ a m B. Sour cherry breeding at Dresden-Pillnitz. Acta Hortic., 2000, 538: 359-362 (doi: 10.17660/ActaHortic.2000.538.62).

10. B u rk ow i c z A. Blumeriella jaapii (Rehm) v. Arx on cultivated stone fruits in Poland. Phytopathologische Zeitschrift, 1964, 51: 419-424.

11. Hodun G., Grzyb Z.S. Field evaluation of susceptibility to Blumeriella jaapii of selected sour cherry cultivars. Acta Hortic., 2000, 538: 151-154 (doi: 10.17660/ActaHortic.2000.538.23).

12. Budan S., Mut a f a I., S to i a n I., P o pe s c u I. Field evaluation of cultivar susceptibility to leaf spot at Romania's sour cherry genebank. Acta Hortic., 2005, 667: 153-158 (doi: 10.17660/ActaHortic.2005.667.22).

13. S juli n T.M., Jon e s A.L., Ande rs e n R.L. Expression of partial resistance to cherry leaf spot in cultivars of sweet sour, duke, and European ground cherry. Plant Dis., 1989, 73(1): 56-61.

14. Zulka D. Die Verwendung von wilden Kirschenarten in der Sortenzüchtung und als Unterlage. Gartenbauwirtschaft DDR, 1971, 36(6): 557-572.

15. S h c he k otova L.A. Biologicheskie osobennosti vozbuditelya kokkomikoza vishni $i$ istochniki ustoichivosti $k$ bolezni. Avtoreferat kandidatskoi dissertatsii [Biological features of cherry coccomycosis causative agent, and genetic resources of coccomycosis resistance]. Michurinsk, 1980 (in Russ.).

16. Ch m i r R.A. Khozyaistvenno-biologicheskaya otsenka vishni $i$ chereshni v srednei polose Rossii. Avtoreferat kandidatskoi dissertatsii [Biological and agronomical characterization of cherries in the Central Russia. PhD Thesis]. Michurinsk, 2003 (in Russ.).

17. C H e b ot a r e v a M.S. Sostav genofonda rodov Cerasus Mill., Padus Mill. i Microcerasus Webb emend. Spach po ustoichivosti $k$ kokkomikozu $v$ svyazi s zadachami selektsii. Avtoreferat kandidatskoi dissertatsii [Gene pool of coccomycosis resistant Cerasus Mill., Padus Mill. and Microcerasus Webb emend. Spach plants for use in breeding. PhD Thesis]. Leningrad, 1986 (in Russ.).

18. S c h u ste r M. Investigation of resistance to leaf spot disease, [Blumeriella jaapi], in cherries. Journal of Fruit and Ornamental Plant Research, 2004, 12: 275-279.

19. Schuster M., Tobutt K. Screening of cherries for resistance to leaf spot Blumeriella jaapii. Acta Hortic., 2004, 663: 239-244 (doi: 10.17660/ActaHortic. 2004.663.38).

20. S c huste r M., Wo $1 \mathrm{f} \mathrm{r} \mathrm{a} \mathrm{m} \mathrm{B.} \mathrm{New} \mathrm{sour} \mathrm{cherry} \mathrm{cultivars} \mathrm{from} \mathrm{Dresden-Pillnitz.} \mathrm{Acta} \mathrm{Hortic.,}$ 2008, 795: 83-86 (doi: 10.17660/ActaHortic.2008.795.6).

21. Wharton P.S., I e z z o ni A., J o n e s A.L. Screening cherry germ plasm for resistance to leaf spot. Plant Dis., 2003, 87(5): 471-477.

22. Wharton P., I e z z o n i A. Development of a protocol for screening cherry germplasm for resistance to cherry leaf spot. Acta Hortic., 2005, 667: 509-514 (doi: 10.17660/ActaHortic.2005.667.75).

23. Kolesnikova A.F., Dzhigadlo E.N. Tezisy nauchno-metodicheskoi konferentsii «Sovershenstvovanie sortimenta $i$ tekhnologii vozdelyvaniya kostochkovykh kul'tur» [Proc. Conf. «Improvement of stone fruit crop assortment and growing technologies»]. Orel, 1998: 97-99 (in Russ.).

24. Fed otova I.E., Koles nikova A.F. Vestnik Bashkirskogo universiteta, 2001, 2(1): 167170 (in Russ.).

25. Gulya eva A.A., D zhigad lo E.N., D zhiga d lo M.I. V sbornike: Selektsiya $i$ sortorazvedenie sadovykh kul'tur [In: Breeding of horticultural crops]. Orel, 2007: 74-80. Available http://www.vniispk.ru/news/sbornik_2007/article.php?id=6. Accessed October 02, 2017 (in Russ.).

26. K a rt a s h o v a O.N. Zimostoikost' $i$ produktivnost' novykh sortov vishni $v$ usloviyakh Nechernozem'ya. Avtoreferat kandidatskoi dissertatsii [Cold resistance and yielding in novel cherry varieties grown in Nechernozemie region. PhD Thesis]. Moscow, 2009 (in Russ.).

27. Ku znetsova A., Voro nov A. Tsvetovodstvo, 2010, 2: 12-14 (in Russ.).

28. Le nivtse va M.S., O re k hova V.P., Luk i c h e va L.A. Ustoichivost' sortov chereshni $i$ 
vishni k kokkomikozu (Coccomyces hiemalis Higg.). Katalog mirovoi kollektsii VIR. Vypusk 799 [Resistance to coccomycosis (Coccomyces hiemalis Higg.) in cherries. Catalog of VIR Whorl Collection. Iss. 799]. St. Petersburg, 2010 (in Russ.).

29. Turovtsev M.I., Turovtseva V.O., Turovtseva N.M. Biologichnii visnik MDPU, 2011, 2: 81-86 (in Russ.).

30. Vishnya Zhivitsa [Zhivitsa cherry]. Available http://sadmordovii.ru/load/sorta_vishni/vishnja_zhivica/6-10-331. Accessed September 29, 2017 (in Russ.).

31. Gelvonauskiene D., Stanys V., St a ni e ne G. Resistance stability to leaf diseases of sour cherry varieties in Lithuania. Journal of Fruit and Ornamental Plant Research, 2004, 12: 295-301.

32. B la ž k o vá J. Resistance to abiotic and biotic stressors in sweet cherry rootstocks and cultivars from the Czech Republic. Journal of Fruit and Ornamental Plant Research, 2004, 12: 303-311.

33. Grzyb Z.S., Rozpara E. Field evaluation of the susceptibility to Blumeriella jaapi and Glomerella cingulata and some biological properties of newly selected sour cherry genotypes. Journal of Fruit and Ornamental Plant Research, 2004, 12: 313-319.

34. $\mathrm{Ch}$ e b a $\mathrm{n}$. Biologicheskie osobennosti chereshni $i$ uluchshenie sortimenta $v$ usloviyakh respubliki Moldova. Avtoreferat doktorskoi dissertatsii [Biological features and improvement of cherries in Moldova. PhD Thesis]. Kishinev 2005 (in Russ.).

35. Borovinova M., Christov N., Nyéki J. Some biological properties of new sweet cherry cultivars in Bulgaria and their susceptibility to Blumeriella jaapii. International Journal of Horticultural Science, 2007, 13(3): 95-97.

36. S c huster M., Grafe C., W o l fra m B. New results of sour cherry breeding in Germany. Acta Hortic., 2014, 1020: 71-73 (doi: 10.17660/ActaHortic.2014.1020.7).

37. S c huste r M., Grafe C., Wolf ram B., S ch midt H. Cultivars resulting from cherry breeding in Germany. Erwerbs-Obstbau, 2014, 56(2): 67-72.

38. Rom anazzi G., Murolo S., B ranzant i B. Resistance of sweet cherry to coryneum and cherry leaf spot. Phytopathology, 2005, 95(6 Supplement): S90 (doi: 10.1094/PHYTO.2005.95.6.S1).

39. Ki rály K., S z e n t p é te ri T. Blumeriella jaapi (Rehm) v. (Arx) infection of some sweet cherry cultivars in two years with different precipitation conditions. International Journal of Horticultural Science, 2006, 12(3): 37-39.

40. Rozs ny y Z., A p o st o 1 J. Breeding for sweet and sour cherry disease resistance in Hungary. Acta Hortic., 2005, 667: 117-122 (doi: 10.17660/ActaHortic.2005.667.15).

41. Ap ostol J. Description of new cherry cultivars and cultivar candidates bred in the Research Institute for Fruitgrowing and Ornamentals. International Journal of Horticultural Science, 2008, 14(1-2): 81-82.

42. Le nivtseva M.S Sbornik nauchnykh trudov po prikladnoi botanike, genetike i selektsii (St. Petersburg), 2012, 170: 66-77 (in Russ.).

43. Mikhe ev A.M., Mes h che ry a k ova I.V. Sbornik nauchnykh rabot NIZISNP, 1978, 12: 67-72 (in Russ.).

44. Mele shkevich A.A. Materialy VI Vsesoyuznogo soveshchaniya po immunitetu sel'skokhozyaistvennykh rastenii [Proc. VI Meeting on immunity of cultivated crops]. Moscow, 1975: 310 (in Russ.).

45. K a n' s h i n a M.V. Trudy Voronezhskogo universiteta, 2007, 1: 73-76 (in Russ.).

46. Zhuk ov O.S., S h che k o tova L.A. Materialy oblastnoi nauchnoi konferentsii «Razvitie nauchnogo naslediya I.V. Michurina» [Proc. Conf. «Development of the I.V. Michurin's ideas»]. Michurinsk, 1981: 34-35 (in Russ.).

47. Z hu k o v O.S. Selektsionno-geneticheskie osnovy i poluchenie vysokokachestvennykh sortov vishni. Doktorskaya dissertatsiya [Genetics and breeding cherry cultivars for high quality. DSc Thesis]. Michurinsk, 2000 (in Russ.).

48. K o l e s n i k ov a A.F., S h c h e k o t o v a L.A. Sbornik nauchnykh rabot VNIIS im. I.V. Michurina, 1985, 44: 12-15 (in Russ.).

49. K o le s ni k ov a A.F. Byulleten' VIR, 1982, 123: 42-44 (in Russ.).

50. F edotova I.E. Ispol'zovanie nekotorykh vidov roda Cerasus Mill. $v$ selektsii vishni na ustoichivost' $k$ kokkomikozu $i$ adaptivnost' $k$ usloviyam sredy. Avtoreferat kandidatskoi dissertatsii [Involvement of some Cerasus Mill. species into cherry breeding for resistance to coccomycosis and adaptiveness. PhD Thesis]. Bryansk, 2000 (in Russ.).

51. Dzhigadlo E.N., Gulyaeva A.A. V sbornike: Selektsiya i sortorazvedenie sadovykh kul'tur [In: Breeding of horticultural crops]. Orel, 2007: 86-95. Available http://www.vniispk.ru/news/sbornik 2007/article.php?id=8. Accessed October 02, 2017 (in Russ.).

52. I s a k o v a M.G. Ural'skii sadovod, 2010, 49: 3 (in Russ.).

53. Che b ot a reva M.S. Sbornik nauchnykh trudov po prikladnoi botanike, genetike $i$ selektsii (St. Petersburg), 1993, 147: 3-8 (in Russ.).

54. G $\mathrm{orb}$ a c h e va N.G. Otsenka poliploidov yabloni $i$ otdalennykh gibridov vishni kak iskhodnykh form $v$ selektsii. Avtoreferat kandidatskoi dissertatsii [Polyploid apple trees and distant hybrids of cherry, as initial breeding forms. PhD Thesis]. Orel, 2011 (in Russ.).

55. F e d o t o va I.E, K o l e s n i k ov a A.F. Uchenye zapiski Orlovskogo gosudarstvennogo universiteta, 2007, 2: 107-113 (in Russ.). 
56. Steg meir T., S chuster M., S ebol A., Rosyara U., Sund in G., I ezzoni A. Cherry leaf spot resistance in cherry (Prunus) is associated with a quantitative trait locus on linkage group 4 inherited from P. canescens. Mol. Breeding, 2014, 34(3): 927-935 (doi: 10.1007/s11032014-0086-3).

57. A p ost ol J. Hungarian resistance breeding in sour cherries. Acta Hortic., 2000, 538: 363-365 (doi: 10.17660/ActaHortic.2000.538.63).

58. Apostol J. Breeding resistant sour cherry varieties in Hungary. Hungarian Agricultural Research, 2000, 1: 16-19.

59. A p o s t o l J. New sweet and sour cherry selections in Hungary. Acta Hortic., 2008, 795: 75-78 (doi: 10.17660/ActaHortic.2008.795.4).

60. A p o stol J. Breeding of sweet and sour cherry in Hungary. Proc. III Conf. "Innovations in fruit growing - improving the production of cherries». Belgrade, 2011: 49-57.

61. Radicevic S., Cerovic R., Lukic M., Paunovic S., Jevremovic D., Milenk ovic S., Mitrovic M. Selection of autochthonous sour cherry (Prunus cerasus L.) genotypes in Feketic region. Geneka, 2012, 44(2): 285-297 (doi: 10.2298/GENSR1202285R).

62. Schuster M., Grafe C., H oberg E., S c h üt z e W. Interspecific hybridization in sweet and sour cherry breeding. Acta Hortic., 2013, 976: 79-86 (doi: 10.17660/ActaHortic.2013.976.7). 